UNIVERSIDADE ESTADUAL DE FEIRA DE SANTANA

Autorizada pelo Decreto Federal $n^{\circ} 77.496$ de 27/04/76

Recredenciamento pelo Decreto $n^{\circ} 17.228$ de 25/11/2016

PPPG

PRÓ-REITORIA DE PESQUISA E PÓS-GRADUAÇÃO

COORDENAÇÃO DE INICIAÇÃO CIENTÍFICA

XXIII SEMINÁRIO DE INICIACCÃO CIENTÍFICA DA UEFS

SEMANA NACIONAL DE CIENTÍFICA E TECNOLÓGICA - 2019

\title{
O REALISMO SOCIALISTA EM MEMÓRIAS DO CÁRCERE: TRANSFIGURAÇÃO LITERÁRIA E TRANSPOSIÇÃO CINEMATOGRÁFICA.
} Karina de Oliveira Mélo ${ }^{1}$; Marcos Cezar Botelho ${ }^{2}$

1. Bolsista PROBIC /UEFS, Graduando em Letras Vernáculas, Universidade Estadual de Feira de Santana, e-mail: kmelooliveira@gmail.com

2. Orientador, Departamento de Letras e Artes , Universidade Estadual de Feira de Santana, e-mail: marcosbotelho.br@gmail.com

PALAVRAS-CHAVE: Memórias do Cárcere; realismo socialista; cinema novo.

\section{INTRODUÇÃO}

O trabalho mapeia o imaginário político, social e cultural construído por Graciliano Ramos na obra biográfica de "Memórias do Cárcere". Problematiza o discurso político do livro contrapondo com o modelo político e cultural chamado de Realismo Socialista, analisando o contraste dessas normas com a autoficção do autor alagoano. O estudo também estabelece um diálogo entre o literário e a adaptação cinematográfica do livro fazendo intertexto entre as duas obras em suas semelhanças de diferenças.

\section{MATERIAL E MÉTODOS OU METODOLOGIA (ou equivalente)}

Dentre os materiais utilizados para desenvolvimento desse estudo estão os dois volumes de Memórias do Cárcere (1963) e a obra fílmica homônima de Nelson Pereira (1984), dentre outros matérias científicos que envolviam a temática. $\mathrm{O}$ método usado para análise foi o comparatista para dialogar entre a obra literária e os filmes.

\section{RESULTADOS E/OU DISCUSSÃO (ou Análise e discussão dos resultados)}

Na obra de autoficção de Graciliano Ramos foi possível observar o contexto social da época través de sua perspectiva. Em "Memórias do Cárcere" (1953) ele retorna a 1936, ano que foi preso sem acusações formais por envolvimento com o PCB, partido e movimento político o qual era perseguido pelos integralistas. No livro o autor fala de sua perspectiva mediante os acontecimentos, sentimentos, conjuntura política e impressões de seus "colegas" de prisão, sempre com uma linguagem muito própria e crítica, porém seu engajamento dentro do Partido Comunista Brasileiro lhe causar contraversões na escrita de Memórias, por causa da estética artística e cultural do Realismo Socialista. A estética cultural soviética trazia consigo uma série de exigências: coletivismo; a figuração do herói positivo e engajamento ideológico socialista e clareza na mensagem (para ser didático); tinha viés propagandista. Analisando a conjuntura da obra percebe-se o motivo pelo qual o autor alagoano sofreu duras críticas do partido em relação a sua autoficção, Graciliano de fato não enaltece o socialismo e nem seus heróis em algumas partes da obra, o que se torna algo fora dos parâmetros do romance social, mas durante o enredo critica veementemente o capitalismo, como todo socialista. Para 
Graciliano Ramos, o romance social devia ser feito do povo para o povo e só assim o Realismo Socialista estaria em contraponto com o realismo burguês, se há alguma palavra que resuma o autor e sua obra é resistência é na resistência do autor que o diretor Nelson Pereira dos Santos, em 1984, faz Memórias do Cárcere transcender das páginas para as telas do cinema nacional na segunda fase do cinema novo. O cinema novo foi para a cinematografia brasileira o que o Modernismo foi para literatura, a reinvenção de uma arte nacional a partir de novas técnicas artísticas que mostravam o Brasil pelos olhos do artista brasileiros. Nelson Pereira, assim como Graciliano Ramos, teve suas aproximações, distanciamentos e atritos com o PCB em relação a sua arte e também criticado duramente pelo partido em seus filmes. Outro fato e comum entre eles é que ambos viveram épocas conturbadas da política brasileira e sem a garantia das liberdades individuais, Graciliano no período ditatorial de Vargas, Nelson na Ditadura Militar de 64, por isso o intertexto entre esses dois autores é muito significativo. É no ano da queda do AI-5 e da censura que o filme é lançado. O filme homônimo a obra do escritor vai contar a história de Graciliano Ramos, fazendo sérias críticas a Vargas, mas também ao período militar, um filme com diversas intenções, e sem desrespeitar a literatura e a vida de Graciliano ele modifica a ordem dos acontecimentos do livro para criar um contexto de crítica e ironia.

\section{CONSIDERAÇÕES FINAIS (ou Conclusão)}

Pode-se concluir que Graciliano Ramos ao escrever Memórias do Cárcere manteve suas convicções apesar das pressões da estética socialista. É um autor emblemático e original que contribuiu de maneira positiva a literatura. Pode-se observar também que o realismo Socialista não teve muita força no Brasil, afinal, o modernismo criou uma identidade de cultura artística nacional e original. Foi visto que o filme de Memórias do Cárcere (1984), é um intertexto de obras e contextos políticos distintos, mas com caracteres afins. Apesar de a adaptação divergir em alguns aspectos da obra literária são unidos por um propósito: a denúncia de governos totalitários, em defender as liberdades individuais e artísticas não se submetendo a censuras.

\section{REFERENCIAS}

ABAURRE, Luiza M.; PONTARA, Marcela. Literatura brasileira: tempos, leitores e leituras. São Paulo: Moderna, 2006.

ANDRADE, Homero Freitas de. O Realismo socialista e suas (in)definições. Revista Literatura e Sociedade - USP, São Paulo, v. 15 n. 13, 2010.

BOSI, A.. A escrita e o testemunho em Memórias do Cárcere. Estudos Avançados (USP. Impresso), v. 9, p. 309-322, 1995.

DAVI, T. N.. Nelson Pereira dos Santos e o cinema brasileiro: trajetórias de luta e renovação. Cadernos da FUCAMP, Monte Carmelo, v. III, p. 97-118, 2004.

FRAZÃO, Dilva. Graciliano Ramos: Escritor brasileiro. Disponível em:<https://www.ebiografia.com/graciliano_ramos/> Acesso em: 13 de Janeiro de 2019. 
FORTE, Graziela Naclério. Arte e Poder: O Realismo Socialista. Novos Temas, v. 9, p. 57-66, 2013.

JOZEF, Bella. Modernismo brasileiro: vanguarda, carnavalização e modernidade. Universidade Federal de Rio de Janeiro.

MORAES, Dênis de. Graciliano, literatura, criação cultural e engajamento - UFF, Rio de Janeiro. Revista Contracampo, n. 15, 2006.

MOURELLE, Thiago Cavaliere. As várias faces de Getúlio Vargas: historiografia e memória (Artigo). In: Café História - história feita com cliques. Disponível em: https://www.cafehistoria.com.br/as-varias-faces-de-vargas. Publicado em: 26 Jul. 2017. Acesso: 13 de Janeiro de 2019.

NOVAES, Cláudio; BOTELHO, Marcos. Transculturalidade e trânsitos intersemióticos: Adaptações e transcriações cinematográficas em Graciliano Ramos. Pontos de Interrogação - Revista de Crítica Cultural, Bahia. v. 8, n. 1, jan.-jun., p. 91-106, 2018.

PAVERCHI, S. R.. Memórias do Cárcere, da palavra à imagem: análise dos aspectos culturais brasileiros presentes no romance e na adaptação para o cinema. In: IX Congress of Brazilian Studies Association (Brasa in NOLA), 2008, New Orleans. Brasa in NOLA, 2008.

RAMOS, Graciliano. Memórias do Cárcere vol. I e II. São Paulo: Círculo do Livro.

RAMOS, Paulo. Memórias do cárcere e a persistência da história. Universidade de São Paulo, 2012.

ROSSI, Vamberto José. As duas faces do primeiro Governo Vargas. Disponível em: $<$ http://www.memoriaoperaria.org.br/revistaeletronica/as-duas-faces-dogoverno.pdf> Acesso: 13 de Janeiro de 2019. 